\title{
Least Developed Countries (LDCs) Ready for M-Government Implementation? : The Case of Malawi
}

\author{
Mr.John Edward Mtingwi \\ University of Pretoria,South Africa
}

\begin{abstract}
The purpose of this research is to investigate the possibility of Mgovernment Implementation in LDCs. M-government implementation is mostly in developed and developing countries. Literature has so far failed to provide any comprehensive M-government implementation in LDCs' $M$ government adoption.

The failure of literature to provide M-government Implementation in LDCs necessitates the exploration of new themes that suits the LDCs to implement M-government to leapfrog Egovernment. The proposed themes for M-government Implementation are intended for use in LDCs to deliver services through M-government.

This research adopted a qualitative research using pragmatism philosophy and explanatory approaches to enhance understanding of the research findings. Case study research is employed, as it utilises realistic data from the proposed knowledgeable participants from selected organisations, ordinary citizens and focus groups in order to create appropriate contribution. The research findings show that most people in LDCs do not have M-government practical experiences. However, most factors such as mobile network providers, mobile phones and a minimal level of human capacity that can develop mobile content to adopt and implement M-government are available. The significance of the findings are that if M-government is implemented, it would assist decision makers to provide comprehensive and appropriate guiding principles to understand the challenges and opportunities of mobile government. The proposed M-government adoption would contribute new knowledge as the themes (Technology, Environment, Organisation and Tasks/Services) would include unexplored constructs and dimensions missing in the existing Mgovernment implementation such as network infrastructure, culture, and political commitment. The themes would influence the generalisation of implementation of M-government in similar settings.
\end{abstract}




\section{CCS Concepts:}

International Telecommunications Union

E-government Development Index

Information Systems Keywords

Leapfrogging; pragmatism; technology; organisation; m-government

\section{INTRODUCTION}

The existing E-government literature highlights the E-government failures in least developed countries (LDCS). Among the factors that contribute to the failures is lack of good information communication technologies (ICTs) infrastructure [37] to enable governments' provision of eservices. LDCs were officially established by the United Nations in 1971 [85] and are referred to countries with lowincomes or poor economic ranks. The poor economic rankings make LDCs suffer from long term impediments to ICT's growth. LDCs have low human resource skills development. They are vulnerable in socialeconomic and environmental stocks [85]. The telecommunication sector in the world has however developed various electronic mobile devices which have penetrated in all societies. These devices have enhanced communication methods among various stakeholders of different economic status worldwide for the last decade. They are also linking citizens with government agencies and business entities. The idea of mobile government (M-government) was initiated as a means communication among stakeholders [18] in developing and developed of countries. LDCs made continuous progress in terms of people having a share of access to mobile ICTs between 2011 and 2014 and in 2010 mobile cellular subscriptions increased rapidly from 33\% to 63\% in 2014 per 100 people [37], [26].

The LDCs scored lowest average of 0.21 in 2014 at the E-government Development Index (EGDI) compared to lower middle-income countries with an average of 0.41 of EGDI [36]. The lowermost score is due to inadequate ICTs infrastructures. The LDCs are not investing significantly in ICTs development, to enhance the progression of Egovernment phases which would foster the delivery of:

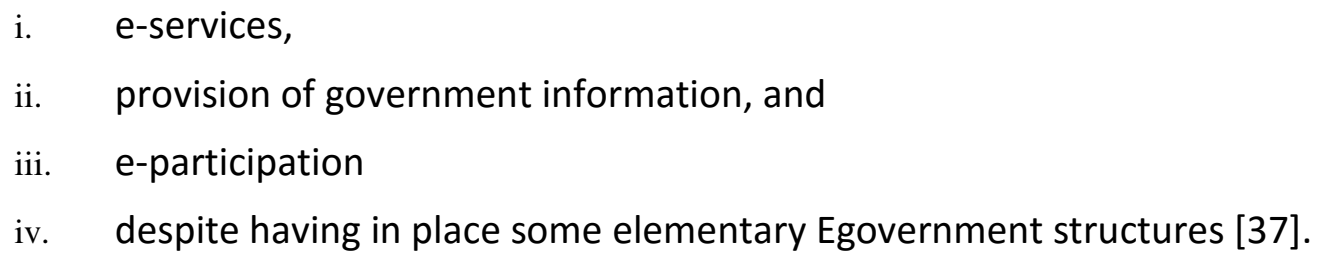




\section{WHY LDCS NEED MOBILE GOVERNMENT}

Governments in LDCs have a problem of delivering quality services to stakeholders on time. The failure to deliver quality services is due to insufficient finances, inadequate expertise, lack of appropriate ICT devices for connectivity and lack of private-public partnerships to develop national telecommunication network backbones [26]. Poor information technology communication infrastructure results in the absence of the national telecommunication network backbone. Almost all LDCs' governments undertook E-government implementations to improve service delivery to various stakeholders. LDCs are ranked the lowest according to the world E-government ranking [36], [37].

One alternative solution is the adoption and use of Mobile government which is the use of mobile phones and other portable communication devices [23] to deliver the services and information through existing mobile network providers [22].

However, LDCs do not have M-government that suit them. Lack of proper M-government adoption is widening the digital gap [24], [26]. As a result, quality differences of available fixed and mobile networks and the basic connectivity, are prevalent between and within LDCs and other countries [26]. The gap between stakeholders and governments in this research is referred to as: Stakeholders and government information sharing gap [29]. This information sharing gap, it is where governments fail to effectively share information and other services with the relevant stakeholders on time because of variances in ICTs development, in LDCs and other countries [29], [26], [24]. The research sought to develop LDCs' specific proposed M-government Adoption Framework that would assist LDCs to adopt mobile government. Information sharing between government and stakeholders through utilisation of mobile technologies could improve if mobile government is adopted.

\section{PURPOSE OF RESEARCH}

Literature has failed to provide any comprehensive M-government deployment [1] for LDCs'. The current adoption models such as Diffusion of Innovations (DIT), Technology Acceptance Model (TAM), and Technology Task Fit (TTF) have not been used for Mgovernment Adoption in LDCs. The purpose of this research is to propose the adoption of M-government for LDCs. The adoption of Mgovernment in LDCs will contribute new knowledge as it includes unexplored constructs and 
dimensions not in the existing Mgovernment implementations. The outcomes of the research would assist decision makers have comprehensive and appropriate guiding principles to understand the challenges and opportunities.

\section{MOTIVATION AND SIGNIFICANCE}

The factors which empowered the researcher to embark on the research in the case study country (Malawi) are:

i. The presence of mobile network providers, mobile phones and other portable devices for communication,

ii. The presence and utilisation of mobile applications in private sector e.g. Banking sector, international nongovernmental organisations in health sector,

iii. Political rhetoric that emphasises that in democratic political system, the people should participate in formulation of policies and decision making at most levels,

iv. The abstraction level of existing technology adoption theories or models which are not consistent with least developed countries

(LDCs) landscape and

v. Conspicuous lack of mobile government literature for LDCS

The research outcomes will guide government's political and technical leadership to make informed decisions. Academic and industrial communities in information systems would appreciate the need for Mgovernment in LDCs to enhance communication and service delivery amongst stakeholders.

\section{RESEARCH QUESTION AND OBJECTIVES}

The research proposes the adoption of M-government in LDCs, and the research question is: What are the core thematic clusters for the implementation of LDCs' M-government Adoption? The following key objectives were used and adhered to respond to the above research question:

i. To identify organisational alignment which suits mobile technologies and possible causes of resistance to change; 
ii. To examine legal frameworks and government policy for mobile technologies;

iii. To assess the level of public-private partnership and stakeholders economic levels which would propel the deployment of mobile government;

iv. To investigate national, organisational and individual cultures towards mobile technologies;

v. To investigate existing mobile: technologies and network providers;

vi. To find what is existing and the gaps

\section{RESEARCH INQUIRY MODE AND APPROACH}

The research utilised qualitative and a pragmatism philosophical paradigm approaches to collect and analyse the data. The researcher developed the proposed theoretic framework figure 3 in section 12 , and was used as a lens to direct the researcher to carefully examine the objectives and questions of the research [40], [72]. Thorough analysis focused primarily on extracting themes and the quotations from the transcribed data which would be linking the themes. In the paper, the researcher uses iterative analytical process using thematic analysis approach [10]. The discovered themes were linked to their theoretical model concepts or constructs for validation or verification. The theoretical constructs would not be measured statistically. The research's methodology is as follows:

Malawi is a research setting (case study) because the country belongs to African least developed countries [5], [27], [37], [28]. Malawi was preferred in the evaluation of the constructs or variables which would be influential to M-government adoption in African LDCs.

Pragmatic philosophical approach is suitable for conducting the research, because worldviews are believed to be constructed socially on a shared agreement [72].

Qualitative research method was adopted for the research in which direct interactive interviews were employed to collect data from participants and reviewing useful literatures [72], [33]. Qualitative research focuses on exploring questions such as what, how and why. The principal idea of qualitative research is the discovery of the meanings rather than quantifying. The case-study used, is compatible with [4] qualitative research approach.

Models for adopting technologies which mobile devices and applications use, need further examinations in course of reviewing related literatures which focus on qualitative analysis of essential constructs. Some constructs from the current models are considered to be part of research theoretic framework development. The developed theoretic framework is a guiding theoretic lens of 


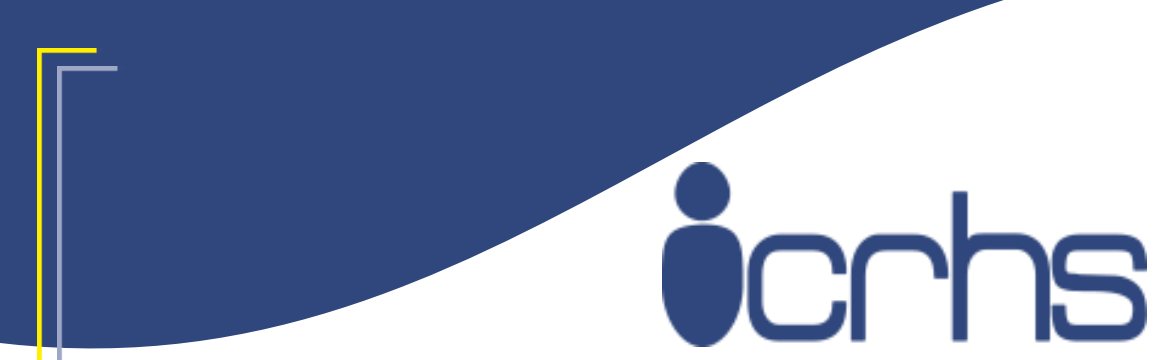

International Conference on Research in Humanities and Social Sciences

Serbia | Belgrade | December 15-17, 2018

a researcher to develop or formulate the investigative design of the research for data gathering, transcribing, cleaning, sorting and analysing [40], [43], [39], [72].

The pragmatist paradigm is supported because it provides for investigation of actions and analysis of research outcomes to improve social reality. Pragmatic researchers deduce the role of prior issues within a specific societal context [6]. It aims at intervening the worldview through actions of human beings [7]. Pragmatism argues that the most important determinant of the research philosophy adopted is the research question. It is a practical approach and integrates different perspectives to collect and interpret the data [3]. Pragmatism employs qualitative strategy because the phenomenon requires an in-depth investigation, explanation and description [2], [4]. Pragmatism appreciates the context in which actions can be undertaken after knowledge has been created to solve existing problems [6], [8].

\section{RESEARCH CONTRIBUTIONS}

It is expected that the research outcomes would guide government's political and technical leadership to make informed decisions. Academic and industrial communities in information systems would appreciate the need for M-government adoption framework for LDCs to enhance communication and service delivery amongst stakeholders. The practical implication is that the proposed adoption framework would guide decision making process for mobile government adoption. Whilst the implementation of the framework would help identify issues relevant to the stakeholders. The research would contribute knowledge for industry practice (mobile network providers and content providers). The knowledge would assist policy and decision making bodies to have a thorough understanding of mobile technologies towards practical implementation of research outcomes of M-government adoption in LDCs. The research has other various contributions:

i. It has made a theoretical contribution because presently there is scanty or no known framework that has been identified for LDCs

[1].

ii. It would contribute literature that increases knowledge and understanding of M-government roles in LDCs.

The methodology implications is that, the research has provided new methodological contribution to the literature, which is associated with M-government adoptability, since most of the influential technology adoption models are based on positivism assumptions. The paper explored the existing 


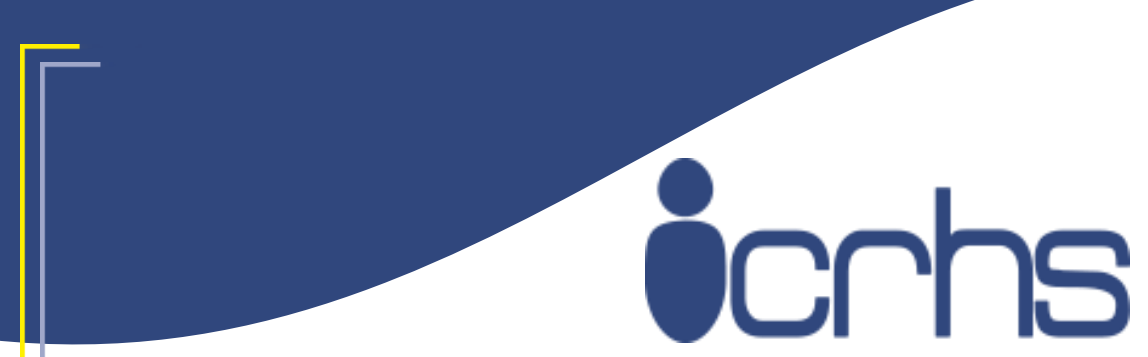

International Conference on Research in Humanities and Social Sciences

Serbia | Belgrade | December 15-17, 2018

mobile technologies, E-government, Mgovernment and technology adoption and acceptance theories. The development of proposed M-government adoption framework was designed and had considered the four global thematic areas which includes: technical issues, organisational issues, environmental issues, and applications/tasks issues.

The outcomes would enhance the satisfactory understanding of government technical staff of what M-government is. The staff will be involved in the implementation of M-government and they will help to transfer M-government knowledge to others. The outcomes will assist the public stakeholders to appreciate the importance of using electronic mobile devices in government organisational activities. The understanding of the outcomes may also help to change the mindset, which is officials' traditional way of providing services to relevant stakeholders. This change will reduce resistance to adopt the use of mobile technologies and adoption of M-government in LDCs.

\section{REEXAMINING E-GOVERNMENT AND M- GOVERNMENT}

The rapid intensification of ICTs usage in government offices resulted in creation of Egovernment to build innovative programs to improve social-economic growth of the country [46]. Egovernment was adopted to process and deliver quality services to stakeholders which lead to innovative management procedures [15]. Four primary Egovernment stakeholders [47] are: citizens, businesses, governments, and employees and these form a network of relations.

M-government converts the functions of E-government through mobile technologies to process data or information, to produce the desired services to stakeholders. Stakeholders are involved in applications descriptions which are linked to M-government focusing on: government to employees (G2E), government (national) to foreign government (G2G) such as embassies and high commissions, government to business partners (G2B) and government to citizenry (G2C).

M-government consist of the following key functions: informational, transactional, operational and managerial [48]. M-government helps government to create a trusted service provision channel [23]. Any LDCs' government should decide to deploy it if possible [25], [27].

Information Systems (IS) research contains number of adoption technological models to assess individual, organisational and societal adoption of new mobile technologies. The models are applied differently, depending on the context of the area of research under investigation. Employment of mobile technologies through Mgovernment would enhance IS researchers knowledge acquisition, policy and decision makers in numerous governments in LDCs appreciate M-governments' adoption.

www.icrhs.org info@icrhs.org 


\section{OVERVIEW OF MOBILE TECHNOLOGIES}

Mobile Technologies (MTs) availability in LDCs is an essential factor for the adoption of Mgovernment. MTs play useful roles because of their abilities to transmit government services to all categories of stakeholders through M-government [38]. MTs comprise wireless connectivity infrastructures such as Wide Wireless Area Network or Wireless Local Area Network (WWAN or WLAN). and compatible mobile devices such as tablets, cellular and smart phones and laptops. MTs are the current and important invention in ICTs advances [38].

LDCs' governments which intend to engage MTs in delivering services should consider utilising advanced features and capabilities of MTs in government and private organisations. MTs support government agencies for speedy exchange of information amongst government organisational stakeholders [30].

Telecommunication growth and ICT development infrastructure have continuously supported MTs utilisation. As a sign of growth, in late 2014, over 6.8 billion mobile-cellular subscriptions worldwide registered (presenting mobile cellular subscription of $96.2 \%$ of population) in quest of ICT development's endeavors [27] and 2015 has over 7 billion cellular subscribers presenting 97\% penetration rate [25]. In LDCs, 89 million people of 940 million people are connected to internet, representing 9.5\% penetration [25]. 61 per cent of the population in LDCs was covered by a mobile broadband signal [86] and the price of mobile broadband services continues to fall rapidly.

The isolated areas in LDCs are increasingly linked through MTs' devices. The services are provided through enormous efforts on the part of mobile technology implementers. Noteworthy, growth of MTs in LDCs and developing countries in recent years is evident. In late 2015, mobile cellular-phone subscriptions infiltration attained $84 \%$ in developing (emerging) countries, and a $29 \%$ increase for LDCs.

All LDCs in 2016, had implemented 3 G mobile broadband networks. The LDCs population of $61 \%$ had access to $3 \mathrm{G}$ mobile broadband services [86] see Figure 1.

By the end of 2016, a total of 26 LDCs had commercially deployed 4G Long-Term Evolution (LTE) networks. 


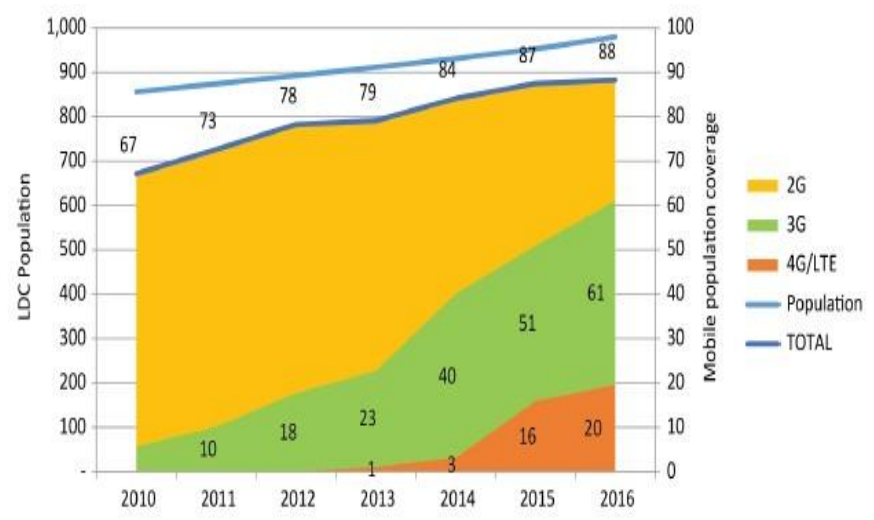

Figure 1: Mobile population coverage in LDCs [86]

There are positive reports of population ration to LDCs' mobile connectivity coverage. LDCs are continuously increasing mobile services availability in hard to infiltrate areas. At the close of 2015, numerous people in LDCs were within signals' range of wireless or mobile coverage. Figure 2 illustrates the growth in percentage of rural population in different regions of the world covered with mobile cellular signals and Africa was at $83 \%$.

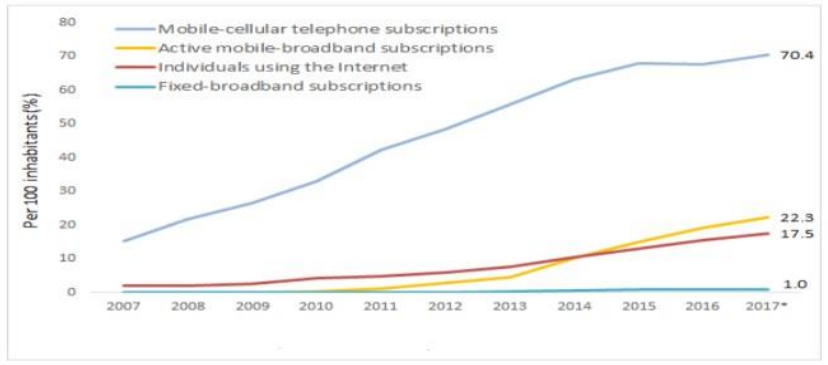

Figure 2: ICT trends in the LDCs Graph

Figure 3: Rural population covered by a mobile-cellular signal, by region, 2003-2012 (source: [24])

\section{MALAWI CASE STUDY CONTEXT}

E-government implementation in Malawi is struggling to take off due to huge financial infrastructure investment requirements. Malawi has not adopted M-government though few private and international organisations have adopted mobile applications such as in: health sector for mobile information processing in hospitals, agriculture sector for agribusiness information to farmers and 


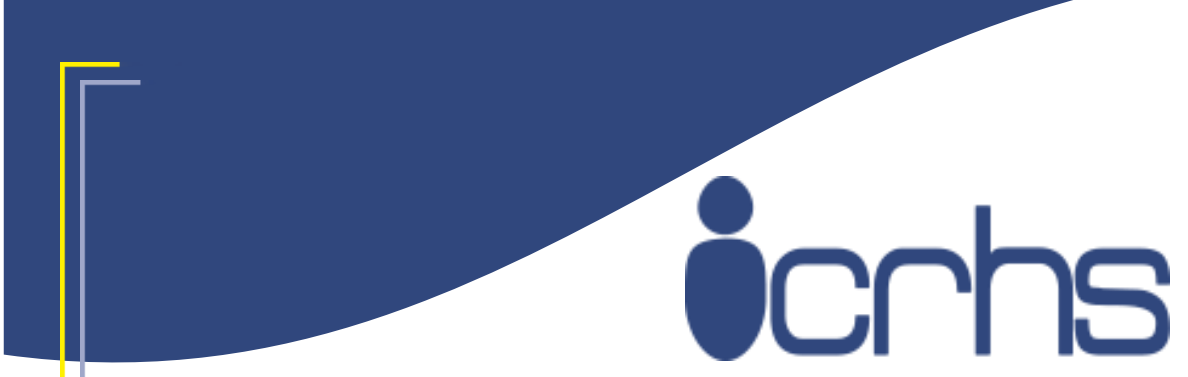

International Conference on Research in Humanities and Social Sciences

Serbia | Belgrade | December 15-17, 2018

other stakeholders and banking sector for banking services. At national level, ICTs development has witnessed the growth of two main mobile network providers namely TNM and Airtel companies.

The E-government status indicates that it has many integrated systems that provide solutions for a particular organisation. The anticipated benefits of E-government in Malawi, were to provide stakeholders with services on time through effective and efficient ways to achieve socio-economic development. Some challenges of E-government implementation in Malawi are: financing problems, lack of political and technical leadership, difficult terrains and inadequate expertise.

Malawi government needs to adopt M-government because it would assist in provision of services to its stakeholders timeously.

The M-government indispensable factors that were reviewed are technological, political, economic and social factors. Mobile network penetration in Malawi is at $32 \%$ and network coverage is almost over $85 \%$.

The existing ICTs instruments in Malawi presently are National ICT Policy, National ICT Master Plan, Electronic Transaction and Cybercrime Act, 2016 and Communications Act, 2016.

ITU [27] provides mobile phone subscribers per 100 people for Malawi from 2000 to 2016 at an average value of 8.21 subscribers per 100 people with a minimum of 0.43 mobile subscribers per 100 people in 2000 and a maximum 40.32 mobile subscribers per every 100 people in 2016 [26], [73], see Figure 2. This indicates that subscribers in Malawi are steadily increasing annually.

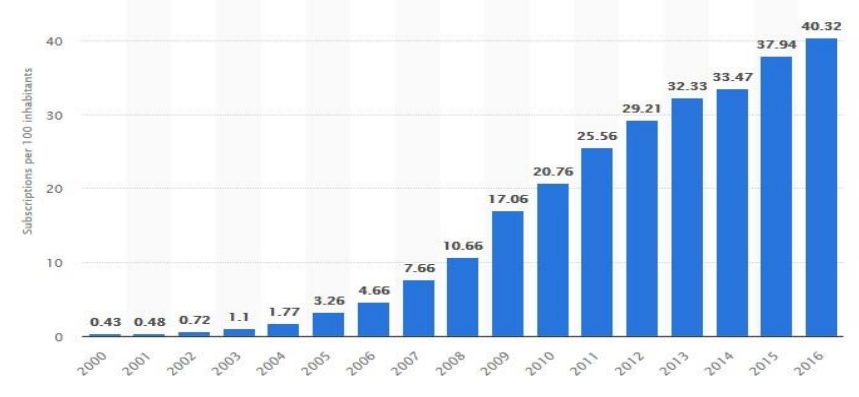

Figure 4: Mobile phone subscribers, per 100 people for Malawi 2000-2016 (source: [27])

Mobile network coverage for Airtel Malawi and TNM is over 95\%. Airtel Malawi is the leading mobile operator in the market. Mobile subscription rate is at 50\% for TNM and Airtel respectively [32]. Malawi has just gained accessibility to intercontinental submarine fibre optic cables through Tanzania and the national fibre backbone is being developed [31]. 


\section{DATA COLLECTION AND ANALYSIS}

Non-probability sampling (purposive sampling) technique is used and focusing on easily accessible and potential participants [9], [10], [11]. To get interview participants, the request letters were sent to different government organisations, private companies and the youth (university students from two universities). Twenty interviews were conducted and the data was transcribed. The researcher did not decide the number of participants and the number was determined by the number of respondents. The research participants were purposefully selected from government and private organisations and the ordinary category (citizens of Malawi). Youthful groups of participants for the focus group interviews were also purposefully selected. The participants were senior ICT and senior non ICT government officers. Senior ICT and senior non ICT participants from private sector. The thematic analysis was used to qualitatively identify, analyse and report themes from the transcribed data [12], [13], [14]. The thematic analysis followed the following process [13]:

i. The data familiarisation: which is reading and re-reading the data.

ii. Coding: generating labels that identify important structures of the data which are significant to answering the research question; after coding the entire dataset, collating codes and relevant data extracts.

iii. Searching for themes: inspecting the codes and collected data to identify broader patterns of meaning; ordering data relevant to candidate theme.

iv. Reviewing themes: checking the candidate themes against the dataset, to determine that they tell a convincing story that answers the research question.

v. Defining and naming themes: developing a detailed analysis of each theme; choosing an informative name for each theme.

vi. Writing: putting together the analytic description and data extracts; contextualizing existing literature in relation to the analysed transcribed data.

\section{M-GOVERNMENT IMPLEMENTATION THEMES}

Kim and Crowston [49] identified some of the limitations of ICT adoption theories as follows: ICT adoption and use theories were considered as one-off event disregarding the evolving ICT use dynamics (users' behaviour on continuous or discontinuous use of ICTs) after adoption, use of the 


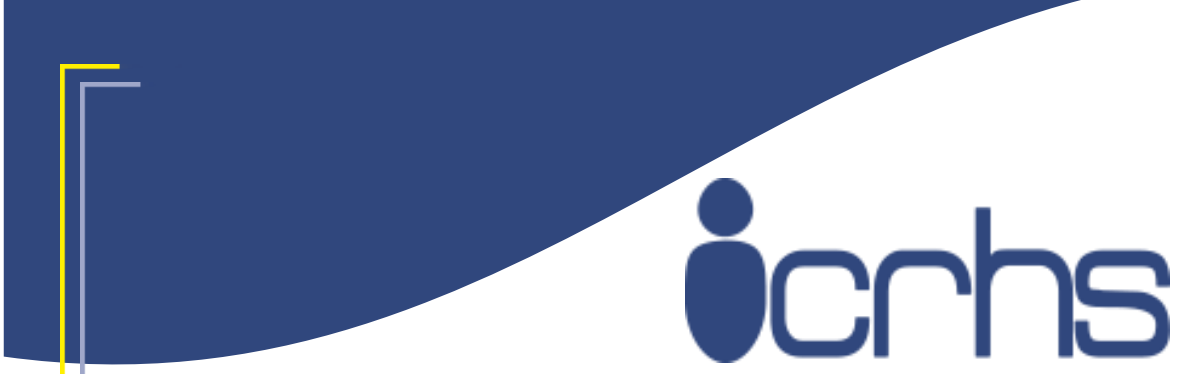

International Conference on Research in

Humanities and Social Sciences

Serbia | Belgrade | December 15-17, 2018

similar or same constructs in different research designs are inconsistent [51] and ICT adoption studies, fail to resolve the context understudy, because they only focused on organisational contextualisation. The limitations of these popular preceding ICT adoption models inspired the formulation of the proposed M-government adoption framework for LDCs. In the proposed adoption framework, tasks or services, demographic pointers and critical factors are indicated which directly or indirectly affect the deployment of M-government. The proposed M-government

Implementation as shown in Figure 5 is consisting of constructs from M-government Value Chain Model [84], TTF, TOE, TAM and UTAUT, M-government framework [16] and the stakeholders in the framework imply that the M-government if adopted would gradually be implemented to cover all national levels regardless of peoples' vicinity and responsibilities.

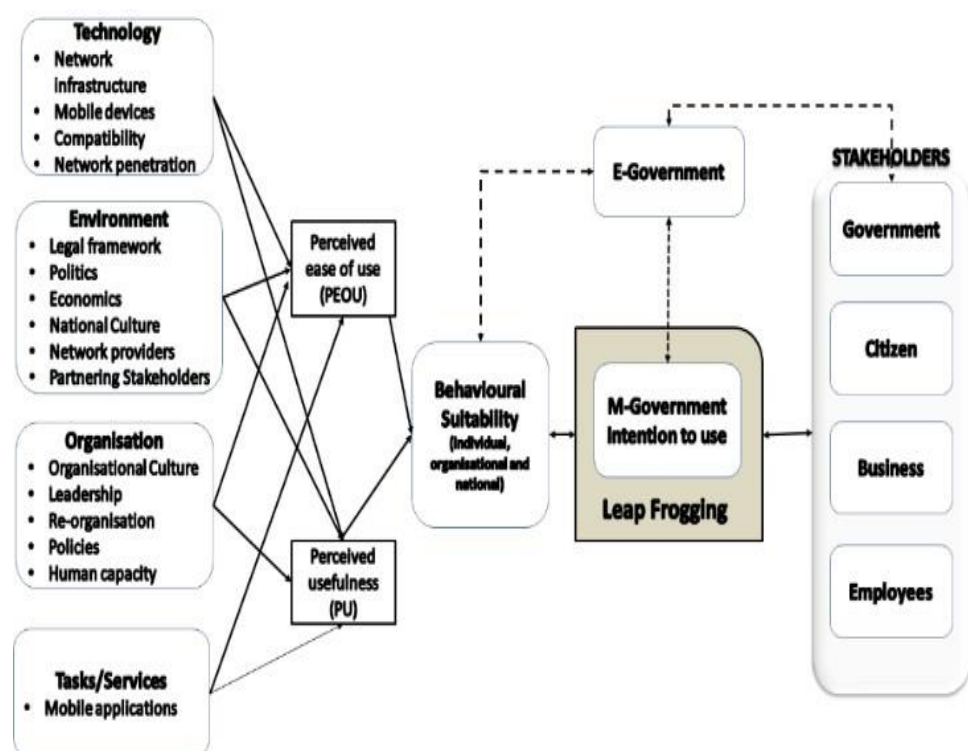

Figure 5: Proposed LDCs M-government Implementation

\section{SUMMARY OF THE THEMES OF PROPOSED MGOVERNMENT ADOPTION IN LDCS (CASE OF MALAWI)}

The proposed M-government Implementation is grouped into four major components or dimensions as outlined: Technology, Environment, Organisation and Tasks/Services which feed into PEOU and PU for validation to determine their importance for their behavioural suitability (at 


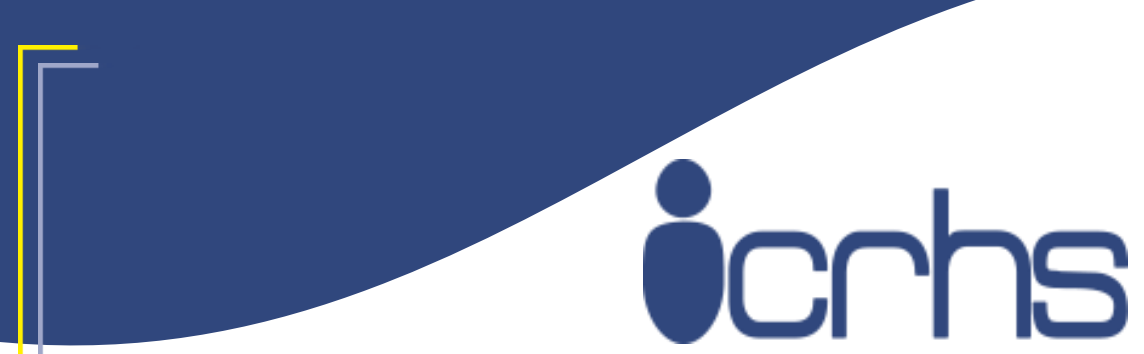

International Conference on Research in Humanities and Social Sciences

Serbia | Belgrade | December 15-17, 2018

individuals, organisational and national levels), for the intention to develop and utilise $\mathrm{M}$ government. The summary of components are discussed below:

General aspects: Most of the research participants have the knowledge of what M-government is but have not used it or do not have practical experience as it is not available in the case study country. Some have used the mobile applications in private organisations such as banks and mobile network providers. The brief is that if the stakeholders in the society are aware of the benefits of Mgovernment, they would influence its adoption. The ages of individuals and literacy levels would influence the adoption and spread of mobile services. For instance, the youths are very active and versatile with mobile technologies compared to older generations. The stakeholders would find $\mathrm{M}$ government useful because they will be interacting with government on real-time basis. It is believed that the M-government will enhance the implementation of E-government in LDCs

Technology Adoption component: This component indicates the mobile network infrastructure development. This includes the approximate number of the population that owns the mobile devices, compatibility of different mobile networks and their related application systems and the network penetration rate in the country [45], [44]. The component also consists of compatible MTs, mobile related software, network infrastructure which is wireless in nature and secure environment [52] and private information storage and transmission [53], [54]. Interoperable and dependable technologies influence M-government adoption [35], [53]. Mobile tools' connectivity encourages the adoption of M-government in many countries [17], [55] and emerging MTs' innovative standards are used to evaluate M-government adoption.

Environment component: This component explores legal framework for mobile technology use in the country [56], [45], political setup that can support the implementation of M-government, the economic empowerment of governments and individuals to afford the acquisition and usage of mobile devices [57], [35]). It explores how national culture will affect the deployment of $M$ government. Finally to explore the reliability of mobile network providers in LDCs and to determine key elements that will enable stakeholders to participate in M-government. Governments in LDCs should deliberately provide laws that promote use of mobile tools [58]. Legal tools regulate the utilisation of MTs to disseminate different informational issues [59] at a very short period [60]. Partnering with other players in the MTs worldwide will greatly enhance M-government adoption in LDCs

[61].

Organisation component: Consists of government organisational culture towards M-government [63], [62] and government leadership style towards the use of mobile technologies in offices [35]). It also deals with the expected re-organisation of government organisation setup, in line with the 


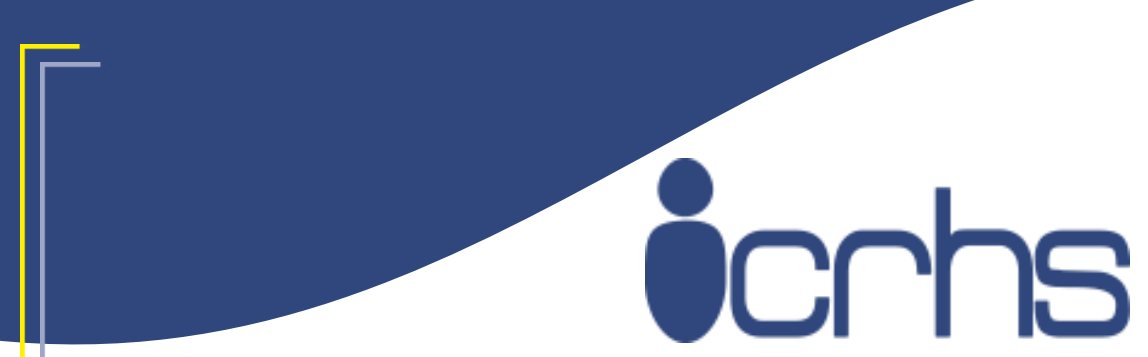

International Conference on Research in Humanities and Social Sciences

Serbia | Belgrade | December 15-17, 2018

existing and upcoming policies such as Egovernment national framework, to suit mobile government applicability. The E-government national framework should have the support of knowledgeable and committed leadership at all applicable levels [64]. It also looks at the human capabilities to manage the whole process of M-government implementation [45]. Users of the organisational information need trusted mobile technologies which preserve their integrity [65]. It is advisable for LDCs to start developing small M-government projects because of their resource constraints and this approach will enable government workers to smoothly understand and adapt the new mobile systems and organisational restructuring [34]. The smooth understanding of Mgovernment development in LDCs will help the key government workers to educate other government officials and stakeholders to adopt M-government [66].

Tasks or Services: The component will explore the likely candidates of mobile applications that will be implemented on M-government in line with government organisational foundations. This requires migrating from existing e-services to $\mathrm{m}$-services or transforming manual systems straight to mobile applications [44]. Governments need to identify tasks that fit into the mobile technologies, organisational needs and the entire environment to provide positive and productive performance for stakeholders [67]. Some of the likely mobile services which will run on M-government infrastructure include the following: $\mathrm{m}$-health, $\mathrm{m}$-disaster, $\mathrm{m}$-participation, meducation, m-agriculture, m-security, $m$-voting, and m-business [68], [21], [69], [70].

\section{LDCS LEAPFROGGING E-GOVERNMENT}

In LDCs, E-government has disappointing challenges [47], [71] that have forced people to migrate mobile technological devices, particularly cellular phones to have access to basic services because cellular phones have lower costs compared to computers costs. MTs are aiming at the minimisation of societal gap for information access which fixed phones failed to bridge. The digital gap can be bridged through the use of wireless or mobile technologies. The MTs can create Mgovernment to provide ubiquitous government. MTs are prerequisites for LDCs to leapfrog Egovernment [36], [74]. Leapfrogging is capable of bypassing traditional E-government developmental procedures to cut costs and timeframe [36]; [19]. Leapfrogging would preserve all crucial requirements to improve communication in LDCs and that leapfrogging to M-government without depending on E-government backbones [22].

Government should be enthusiastic to engage MTs to deliver the required services to stakeholders. $\mathrm{M}$-government structure is built on E-government structure where it exists or M-government can be 
developed from the scratch where E-government is nonexistent, for example in rural sites where there is no any physical ICT infrastructure to support connectivity of ICTs.

\section{RESEARCH LIMITATIONS AND FUTURE RESEARCH}

The major limitations of the research is that no any LDC has Mgovernment practical experiences. The participants worries of their privacy and security of personal data requires further research on cyberspace security in line with least developed countries.

There is need for further research on M-government adoption framework for LDCs. The proposed framework provides new lenses through which researchers can study M-government adoption and implementation in LDCs.

\section{CONCLUSION}

Least developed countries are utilising mobile technologies to improve information communication through social network, in response to the needs of the stakeholders. LDCs should use whatever current mobile technologies they have to process the information and deliver services to the beneficiaries who own mobile devices. The mobile devices can offer $\mathrm{m}$-governance platforms to bridge stakeholders and governments in real-time environment. The use of mobile devices enable governments in LDCs to make huge investment savings. Mobile network providers could work on content in collaboration with all relevant stakeholders and provide direction on appropriate contents which suit mobile devices for the betterment of mobile networks connectivity. Government deliberate policy plans should be developed to develop capacity of ICT professionals in LDCs in areas of mobile applications development and application of privacy and security issues.

Both professional and political leadership should have the willingness to utilise ICTs in government processes to provide services for socialeconomic development. The Ministry of ICT through Department of E-government should champion adoption of M-government in various public agencies.

The legal frameworks are important in LDCs to regulate the mobile technology telecommunication industry such as social networks and internet cyberspace activities. For instance the case study country (Malawi) has Communication Act 2016, Electronic Transaction and Cybersecurity Act 2016, 


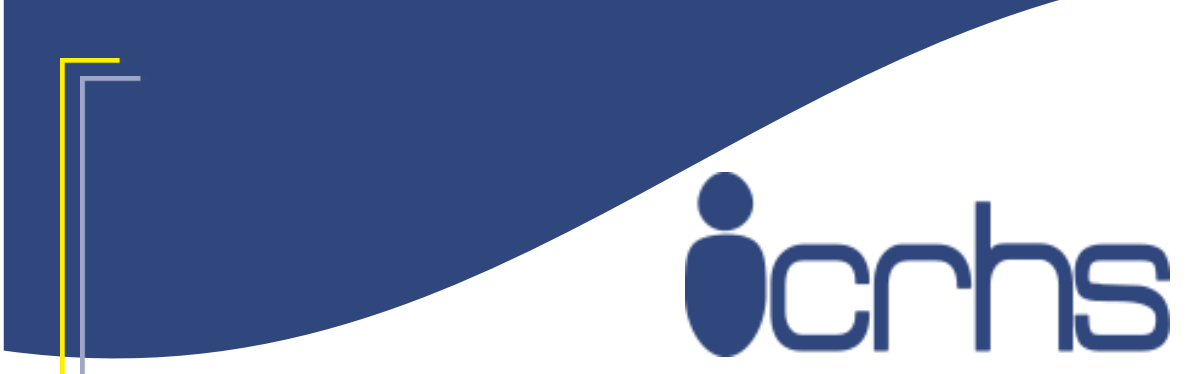

International Conference on Research in Humanities and Social Sciences

Serbia | Belgrade | December 15-17, 2018

National ICT policy but there is no serious enforcement or policing of these legal frameworks to benefit the stakeholders.

Economically, the participants complain about mobile network providers' high pricing of mobile phones' services. At the same time mobile network providers complain that government through the regulator is demanding or charging huge various tax fees which are passed on to mobile phone users. These economic stakeholders' complaints need government interventions of sustainable economic policies that lessen mobile device users' financial burden and promote mobile technological investment.

Governments in LDCs should involve the stakeholders in the selection of mobile applications and contents for processing and transmission. For Malawi, interaction challenges between government and various stakeholders could be improved if M-government could be adopted and operationalised. It should be appreciated that M-government is a viable option for the transformational Egovernment advances in Malawi.

LDCs governments should learn from private organisations which are using mobile applications in the country or from other countries. The study has shown that Malawi has all the needed factors (mobile technology establishments) for the adoption of M-government using the proposed M-government Adoption Framework. The stakeholders are enthusiastic to engage government services using mobile devices and that government should lead by supporting and promoting mobile ICTs usage. The numbers of mobile subscribers have increased approximately in millions and that the government of Malawi could engage to pilot the appropriateness of any mobile application on the adopted $\mathrm{M}$ government.

All research study participants' responses highlighted same worldwide challenges of M-government as indicated in [75], [53], [16], [23]. In many least developed countries, these challenges can be addressed along the operational M-government processes if adopted.

\section{REFERENCES}

[1] Munyoka, W., and Manzira, M. F. 2014. From E-Government to MGovernment - Challenges Faced by Sub-Saharan Africa. Dubai, UAE, Proceeding of the International Conference on Computing Technology and Information Management.

[2] Robson, C. 2002. Real World Research. 2nd ed. Oxford: Blackwell. 
International Conference on Research in

Humanities and Social Sciences

Serbia | Belgrade | December 15-17, 2018

[3] Saunders, M., Lewis, P., and Thornhill, A. 2009. Research Methods for Business Students. 5 ed. Essex CM20 2JE, England: Pearson Education Limited.

[4] Yin, R. K. 2003. Case Study Research: Design and Methods. 3rd ed. Newbury Park. CA: SAGE.

[5] Creswell, J. W. 2009. Research Design: Qualitative, Quantative, and Mixed Methods Approaches. 3rd ed. Thousands Oaks, California: SAGE.

[6] Goldkuhl, G. 2004. Meanings of Pragmatism: Ways to conduct information systems research. Sweden, 17-18 March, Linköping University, pp. 1-15.

[7] Braa, K. and Vidgen, R. 1999. Interpretation, Intervention and Reduction in the Organisational Laboratory: A Framework for incontext Information Systems Research. Accounting, Managaement and Information Technology, Volume 9, pp. 25-47.

[8] Goldkuhl, G. 2012. Pragmatism vs Interpretivism in Qualitative Information Systems Research. European Journal of Information Systems, 21(2), pp. 135-146.

[9] Cavana, R. Y., Delahaye, B. L., and Sekaran, U. 2001. Applied Business Research: Qualitative and Quantitative Methods. Milton, Queensland, Australia: John Wiley and Sons.

[10] Sekaran, U. 2003. Research Methods for Business, a Skill Building Approach. 2 ed. New York: John Wiley and Sons.

[11] Bryman, A. 2012. Social Research Methods. 4th ed. New York: Oxford University Press Inc.

[12] DeCuir-Gunby, J. T., Marshall, P. L., and Mcculloh, A. W. 2011.

Developing and Using a Codebook for Analysis of Interview Data: An Example from a Professional Development Research Project. Field Methods, 23(2), pp. 136-155.

[13] Braun, V., and Clarke, V., 2006. Using Thematic Analysis in Psychology. Qualitative Research in Psychology, 3(2), pp. 77-101.

[14] Attride-Sterling, J. 2001. Thematic Networks: An Analytic Tool for Qualitative Research. Qualitative Research, 1(3), pp. 385-405.

[15] Carroll, J. 2005. Risky Business: Will Citizens accept M-government in the Long Term. Mobile Government Consortium International LLC. Brighton, UK: University of Sussex.

[16] Carroll, J. 2006. What's in It for Me?': Taking M-Government to the People. Slovenia, 19th Bled eConference on eValues, June 5 - 7.

[17] Chen, L. and Nath, R. 2004. A Framework for Mobile Business Applications. International Journal of Mobile Communications, 2(4), pp. 368-381. 
International Conference on Research in

Humanities and Social Sciences

Serbia | Belgrade | December 15-17, 2018

[18] Gosebo, N. and Obono, S. D. E. 2012. Revisiting the Theory of Planned Behaviour for the Preparation of the Adoption of Municipal eservices in Less Developed Countries. SAICSIT, pp. 159-166.

[19] ILO, 2001. World Employment Report 2001-Key Findings, Geneva, March: International Labour Organisation.

[20] Informata, 2011. Mobilising Public Services in Africa: The Mgovernment Challenge. Informa UK Ltd. All rights reserved, 15 September, pp. 30-40.

[21] Lallana, E., 2004. E-Government for Development M-Government: Mobile/Wireless Applications in Government. [Online] Available at: http://www.egov4dev.org/topic4.htm [Accessed 26 July 2015].

[22] Mtingwi, J. and Van Belle, J. P. 2012. The State of E-Government and M-Government Readiness in Malawi. International Journal of Information Technology and Computer Science (IJITCS), 6(1), pp. 120.

[23] Kushchu, I. and Kuscu, H. 2003. From E-government to Mgovernment: Facing the Inevitable. Trinity College, In Proceeding of European Conference of E-government (ECEG).

[24] ITU, 2015a. Measuring the Information Society (MIS) Report, $\mathrm{CH}$ -

1211 Geneva Switzerland: International Telecommunication Union.

[25] ITU, 2015. ICT Facts and Figures, Geneva, Switzerland: International Telecommunication Union.

[26] ITU, 2016a. Measuring the Information Society Report, Geneva Switzerland: International Telecommunication Union Place des Nations $\mathrm{CH}-1211$.

[27] ITU, 2016. ICT Facts and Figures 2017, Geneva 20 - Switzerland: International Telecommunication Union Place des Nations 1211.

[28] UNCTAD, 2016. The Least Developed Countries Report 2016. UNCTAD secretariat at: Palais des Nations, CH-1211 Geneva 10, Switzerland. United Nations Publication. New York. http://unctad.org/en/PublicationsLibrary/ldc2016_en.pdf

[29] Khan, M. A. 2016. Exploring the Push and Pull Drivers in MGovernment Framework that Influence Acceptance of Services on Mobile Devices. International Journal of Computer Science and Network Security (IJCSNS), 16(2), pp. 23-26. 
International Conference on Research in

Humanities and Social Sciences

Serbia | Belgrade | December 15-17, 2018

[30] Moon, J. 2004. From E-government to M-government? Emerging Practices in the Use of MT by State Governments. [Online] Available at:

http://davidjf.free.fr/new/Xmobile_moonreport2.pdf [Accessed 02 May 2015].

[31] Markets and Research, 2016. Malawi - Telecoms, Mobile and Broadband - Statistics and Analyses 2016 - Research and Markets.

[Online] Available at:

http://www.researchandmarkets.com/reports/3951952/malawitelecoms-mobile-andbroadband [Accessed 23 November 2016].

[32] MACRA, 2012. Country report on telecommunication status in Malawi, Blanytre, Malawi: Malawi Communication Regulatoty Authority.

[33] Myers, M. D. 2013. Qualitative Research in Business and Management. London: SAGE.

[34] Syamsuddin, I. 2011. Evaluation of E-government Initiatives in developing countries: An ITPOSMO Approach. International Research Journal of Applied and Basic Sciences, 2(12), pp. 439-446.

[35] Tornatzky, L. G., and Fleischer, M. 1990. The Processes of Technological Innovation. Massachusetts: Lexington Books, Lexington.

[36] UNDESA, 2014. E-government for the future we want: United Nations E-government Survey 2014, New York: United Nations Department of Economic and Socila Affairs.

[37] UN-OHRLLS, 2016. State of the Least Developed Countries, New York, NY 10017, USA: United Nations Office of the High

Representative for the Least Developed Countries, Landlocked DevelopingCountries and Small Island Developing States.

[38] Varshney, U., and Vetter, R. 2000. Emerging Mobile and Wireless Networks. Communications of the ACM, 43(6), pp. 73-81.

[39] Walsham, G. 1995. Interpretive Case Studies in IS Research: Nature and Method. European Journal of Information Systems, 4(2), pp. 7481.

[40] Walsham, G. 2006. Doing Interpretive Research. European Journal of Information Systems. Volume 15, pp. 20-30.

[41] Sun, H., and Zhang, P. 2006. The Role of Moderating Factors in User Technology Acceptance. International Journal of Human-Computer Studies, 64(2), pp. 53-78. 
International Conference on Research in

Humanities and Social Sciences

Serbia | Belgrade | December 15-17, 2018

[42] Venkatesh, V., Morris., M. G., Davis, G. B., and Davis, F. D. 2003. User Acceptance of Information of Technology: Toward A Unified View. MIS Quarterly, 27(3), pp. 425-478.

[43] Miles, M. B., and Huberman, A. M. 1994. Qualitative Data Analysis: An Expanded Source book. Thousand Oaks: SAGE.

[44] Gebauer, J., and Shaw, M. 2002. A Theory of Task/Technology Fit for Mobile Applications to Support Organisational Processes. Working Paper,. Illinos: University of Illinois at UrbanaChampaign.

[45] Fasanghari, M., Amalnick, M. S., and Khatibi, V. 2010. A Proposed Framework for Mgovernment Development Assessment. s.l., Networked Computing (INC), pp. 1-5.

[46] Banerjee, P., and Chau, P. Y. K. 2004. An Evaluative Framework for Analysing E-government Convergence Capability in Developing Countries. Electronic Government, an International Journal, 1(1), pp. 29-48.

[47] Ndou, V. 2004. E-Government for Developing Countries: Opportunities and Challenges. The Electronic Journal on Information Systems in Developing Countries, 18(1), pp. 1-24.

[48] Norris, D. F., and Moon, M. J. 2005. Advancing E-government at the Grassroots: Tortoise or Hare?. Public Administration Review, 65(1), pp. 64-75.

[49] Kim, Y., and Crowston, K. 2011. Technology Adoption and Use Theory Review for Studying Scientists' Continued Use of Cyberinfrastructure. New Orleans, LA, Proceedings of the American Society for Information Science and Technology (ASIST) Annual Conference, October 2011.

[50] Chin, W. W., Marcolin, B. L., and Newsted, P. R. 2003. A Partial Least Squares Latent Variable Modeling Approach for Measuring Interaction Effects: Results from a Monte Carlo Simulation Study and

Voice mail Emotion/Adoption Study. Information Systems Research, 14(2), pp. 21-41.

[51] Limayem, M., Cheung, C. M., and Chan, G .W. W. 2003. Explaining Information Systems Adoption and Post-Adoption: Toward an Integrative Model. s.I., International Conference on Information Systems (ICIS 2003 Proceedings).

[52] Shah, J. R., and Murtaza, M. B. 2005. Effective Customer Relationship Management through Web Services. Journal of Computer Information Systems, 46(1), pp. 98-109. 
International Conference on Research in

Humanities and Social Sciences

Serbia | Belgrade | December 15-17, 2018

[53] Sheng, H., and Trimi, S. 2008. M-government: Technologies, Applications and Challenges.

Electronic Government, An International Journal, 5(1), pp. 1-18.

[54] Kuan, K. K. Y., and Chau, P. Y. K. 2001. A Perception-Based Model for EDI Adoption in Small Business Using a TechnologyOrganisation-Environment Framework. Information and Management, 38(8), pp. 507-512.

[55] Malladi, R., and Agrawal, D. P. 2002. Current and Future Applications of Mobile and Wireless Networks. Communication of the ACM, 45(10), p. 144-146.

[56] Delmas, M. A. 2002. The Diffusion of Environmental Management Standards in Europe and in the United States: An Institutional Perspective. Policy Sciences, 35(1), pp. 91-119.

[57] Crook, C. W., and Kumar, R. L. 1998. Electronic Data Interchange: A Multi-Industry Investigation Using Grounded Theory. Information and Management, 34(2), pp. 75-89.

[58] Xu, S., Zhu, K., and Gibbs, J. 2004. Global Technology, Local

Adoption: A Cross-Country Investigation of Internet Adoption by Companies in the United States and China. Electronic Markets, 14(1), pp. 13-24.

[59] Vincent, J., and Harris, L. 2008. Effective use of mobile communications in eGovernment: How do we reach the tipping point?. Information, Communication and Society, 11(3), pp. 395-413.

[60] Hermanns, H. 2008. Mobile Democracy: Mobile Phones as Democratic Tools. Politics, 28(2), pp. 74-82.

[61] Zhu, K., Kraemer, K. L., and Xu, S. 2003. E-Business Adoption by

European Firms: A Cross-Country Assessment of the Facilitators and Inhibitors. European Journal of Information Systems, 12(4), pp. 251268.

[62] Hofstede, G. 2001. Culture's Consequences: Comparing Values, Behaviors, Institutions, and Organisations across Nations. 2 ed. Thousands, California: SAGE.

[63] Hofstede, G. 2009. Cultural Dimensions: South Africa Cultural Dimensions. [Online] Available at: http://www.geerthofstede.com/hofstede_south_africa.shtml [Accessed 18 August 2015].

[64] Krishna, S., and Walsham, G. 2005. Implementing Public Information Systems in developing countries: learning from a success story. Information Technology for Development, 11(2), pp. 123-140. 
International Conference on Research in

Humanities and Social Sciences

Serbia | Belgrade | December 15-17, 2018

[65] Rao, S., and Troshani, I. 2007. A Conceptual Framework and

Propositions for the Acceptance of Mobile Services. Journal of Theoretical and Applied Electronic Commerce Research, 2(2), pp. 6173.

[66] Khalifa G., Irani Z., Baldwin L. P., and Jones S. 2004. Evaluating Information Technology with You in Mind. The Electronic Journal of Information Systems Evaluation, 4(5), pp. 246-252.

[67] Irick, M. L. 2008. Task-Technology Fit and Information Systems Effectiveness. Journal of Knowledge Management Practice, 9(3), pp. 1-5.

[68] Rain, R., and Maarja, S. 2005. Mobile Services in Tartu Existing services, best practices methodology and suggestions for future development, Tartu, Estonia: Mobile Solutions Ltd.

[69] Ghyasi, A. F., and Kushchu, I. 2004. M-government: Cases of Developing Countries. [Online] Available at: http://unpan1.un.org/intradoc/groups/public/documents/apcity/unpan04 0050.pdf [Accessed 12 March 2015].

[70] Ewan, M. 2006. Dubai has ambitious targets for m-government system. [Online] Available at:

http://www.smstextnews.com/2006/09/dubai_leading_m.html [Accessed 24 August 2015].

[71] Heeks, R. 2003. Most eGovernment-for-Development Projects Fail:

How Can Risks be Reduced? (iGovernment working paper series; No. 14). Manchester, University of Manchester, pp. 1-17.

[72] Creswell, J. W. 2009. Research Design: Qualitative, Quantative, and Mixed Methods Approaches. 3rd ed. Thousands Oaks, California: SAGE.

[73] Global Economy, 2016. The Global Economy. [Online] Available at: http://www.theglobaleconomy.com/Malawi/Mobile_phone_subscriber s/ [Accessed 16 October 2016].

[74] El-Kiki, T., and Lawrence, E. 2006. Government as a Mobile Enterprise: Real-time, Ubiquitous Government. Las Vegas, NV, 2006 Proceedings. Third International Conference on Information Technology (ITNG): New Generation 2006, pp. 320-327.

[75] Lanwin, B. 2002. A Project of Info Dev and The Center for Democracy and Technology: The E-government handbook for developing countries. s.I.:s.n.

[76] Rogers, E. M. 1995. Diffusion of Innovations (4th Edition). New York: The Free Press. 
International Conference on Research in

Humanities and Social Sciences

Serbia | Belgrade | December 15-17, 2018

[77] Davis, F. 1986. A technology acceptance model for empirically testing new end-user information system: theory and results, Doctoral Dissertation, Sloan School of Management, Massachusetts Institute of Technology.

[78] Davis, F. 1989. Perceived usefulness, perceived ease of use, and user acceptance of information technology, MIS Quarterly, 13(3), pp. 319340.

[79] Davis, F. 1993. User acceptance of information technology: system characteristics, user perceptions and behavioral impacts. International Journal of Machine Studies, 38(3), 475488.

[80] Goodhue, D., and Thompson, R. 1995. Task-technology fit and individual performance, MIS Quarterly, 19(2), 213-236.

[81] Alharbi, S., and Drew, S. 2014 Using the Technology Acceptance Model in Understanding Academics' Behavioural Intention to Use Learning Management Systems, International Journal of Advanced Computer Science and Applications (IJACSA), 5(1), pp. 143-155.

[82] Calisir, F., Gumussoy, C. A., and Bayram, A. 2009. Predicting the behavioural intention to use enterprise resource planning systems - An exploratory extension of the technology acceptance model, Management Research News, 32(7), pp. 597-613.

[83] Sun, Y., Bhattacherjee, A., and Ma, Q. 2009. Extending technology usage to work settings: The role of perceived work compatibility in ERP implementation, Information and Management, 46, pp. 351-356.

[84] ITU and OECD, 2011. M-Government: Mobile Technologies for Responsive Governments and Connected Societies. ITU (International Telecommunication Union) and OECD (Organisation for Economic Co-operation and Development), Geneva, Switerland: International Telecommunication Union.

[85] ITU, 2017. Least developed Countries, Commited to connectng the world

[86] ITU, 2018. ICTs, LDCs and the SDGs Achieving universal and affordable Internet in the least developed countries, International

Telecommunication Union Telecommunication Development Bureau Place des Nations $\mathrm{CH}-1211$ Geneva 20 Switzerland 